\title{
Genetic Identification of Freshwater Fish Species Through DNA Barcoding from Lake Lebo Taliwang, West Nusa Tenggara
}

\author{
Tuty Arisuryanti ${ }^{1 *}$, Rika Lathif Hasan ${ }^{1}$, Khadija Lung Ayu ${ }^{1}$, Nofita Ratman ${ }^{1}$, Lukman Hakim ${ }^{1}$ \\ 1) Laboratory of Genetics and Breeding, Faculty of Biology, Universitas Gadjah Mada, Jl. Tehnika Selatan Sekip Utara, Yogyakarta \\ 55281, Indonesia
}

*Corresponding author, email address: tuty-arisuryanti@ugm.ac.id

\section{Keywords:}

genetic identification

freshwater fish

Lake Lebo Taliwang

DNA barcoding

Article history:

Submitted 27/05/2019

Revised 16/09/2019

Accepted 24/09/2019

\begin{abstract}
Lake Lebo Taliwang is one of the lakes in the West Nusa Tenggara with high freshwater fish species diversity. However, the species identification of freshwater fish species from Lake Lebo Taliwang using DNA barcoding is very limited. Therefore, the objective of this study was to identify seven samples of freshwater fish species collected from Lake Lebo Taliwang based on COI mitochondrial gene as a DNA barcoding marker and establish library COI sequences of Indonesian freshwater fish. We are using a standard DNA analysis and data obtained from this study was then examined using Nucleotide BLAST and the phylogenetic tree was analyzed using the Neighbour-Joining (NJ) method with Kimura 2 Parameter (K2P) model. The results revealed that among the seven samples of freshwater fishes collected from the Lake Lebo Taliwang, three samples were identified as Anabas testudineus, the other three samples were Barbodes binotatus and one sample was Trichopodus trichopterus. The level of similarity of these freshwater fish samples referred to the database from the GenBank and BOLD was between 98 $-100 \%$. The NJ tree supports the clade of each species identified in this study. This occurrence indicated that DNA barcoding by using the COI mitochondrial gene was proven to be able to identify the freshwater fish samples accurately.
\end{abstract}

\section{INTRODUCTION}

Indonesia is an archipelago country with more than 17,000 islands and has high biodiversity including freshwater fish diversity, either living in the lakes, rivers, or swamps. Indonesia also has more than 840 lakes, and 17 of the lakes are located in the West Nusa Tenggara Province (NTB) (Haryani, 2013). One of the lakes located in West Nusa Tenggara is Lake Lebo Taliwang. Lake Lebo Taliwang is located in the two districts in the West Sumbawa Regency which are Taliwang District and Seteluk District. Taliwang District and Seteluk District are located around $\pm 15 \mathrm{~m}$ above sea level and $\pm 50 \mathrm{~m}$ above sea level, respectively. The water in Lake Lebo Taliwang comes from Suning River, Seran River, and flood overflow from Brang Rea River, with the total catchment area of $86 \mathrm{~km}^{2}$ from West Seteluk direction. The total area of Lake Lebo Taliwang is $70 \%$ located in Taliwang District, and the rest 30\% is located in Seteluk District. Many kinds of commercially freshwater fish inhabit in this area such as grass carp, climbing perch, barb fish, swamp eel, and striped snakehead (RIPED, 2008). All of the freshwater fish inhabited at Lake Lebo Taliwang is commonly identify morphologically which is usually inaccurate and incorrect. This is due people identify the fish based on their morphology $y_{2}$ which commonly similar between one and another, for example, between climbing perch and gourami (RIPED, 2008). Therefore, molecular identification using the COI gene as a DNA barcoding marker is needed to investigate the correct species name of the freshwater fish collected from Lake Lebo Taliwang. This is due to COI gene as a DNA barcoding marker has many advantages such as it can be used for small amount samples, all of the life stages, and differentiation between similar phenotypes of fish (Dudu et al., 2016).

The application of DNA barcoding in the form of sequence data of cytochrome c oxidase subunit I mitochondrial gene (mtDNA-COI) has been extensively used for taxonomy study and 


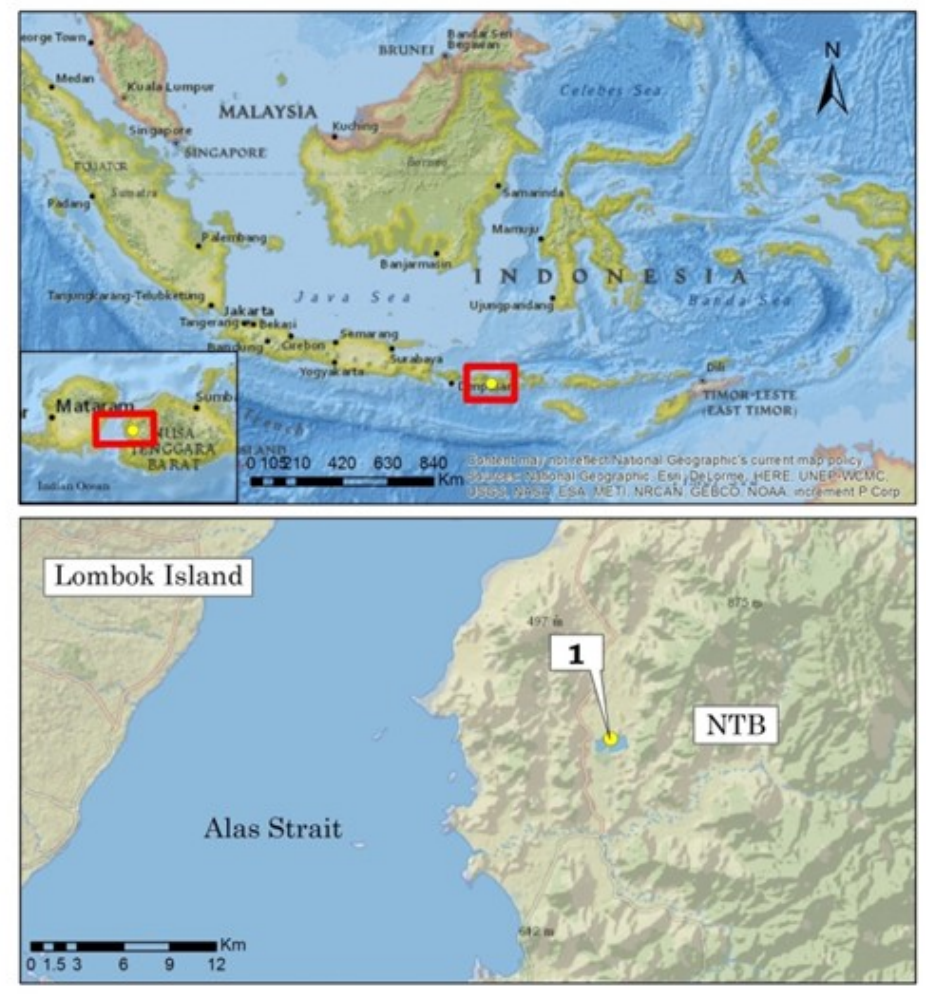

Figure 1. Map of sampling collection sites for freshwater fish samples in Lake Lebo Taliwang,

organism identification (Hebert et al., 2003; Arif and Khan, 2009; Chauhan and Rajiv, 2010; Yudhistira and Arisuryanti, 2019). Besides, it has been useful for the identification of genetically divergent wild stocks of conservation significance for a number of fish species such as mudskipper (Arisuryanti et al., 2018), marine eels (Peninal et al., 2017), and Asian red catfish (Syaifudin et al., 2017). It is now considered highly desirable to include sequences from mitochondrial COI gene to identify freshwater fish species accurately (Dahruddin et al., 2017; Hutama et al., 2017). This is due to proper species database information can be implemented for conservation and breeding program. Therefore, the objective of this study was to identify freshwater fish species collected from Lake Lebo Taliwang using COI mitochondrial gene as a DNA barcoding marker and establish COI sequence library of freshwater fish in Indonesia, especially from Lake Lebo Taliwang, West Nusa Tenggara.

\section{MATERIALS AND METHODS}

Sample Collection, DNA extraction, amplification, and sequencing

Twenty freshwater fish samples were collected from Lake Lebo Taliwang, West Nusa Tenggara (Figure 1) either from fisherman or by hand net. From the twenty samples which were caught in the field, we grouped three fish group based on their similar phenotypes and chose seven samples as a representative of the three group fish samples. Then, a cube of lateral muscle $(6-8 \mathrm{~mm})$ from the left side of the fish was exercised for DNA extraction. The muscle tissue was put into a $1.5 \mathrm{ml}$ sterile tube and preserved in 99\% ethanol. All samples were then brought to the Laboratory of Genetics and Breeding, Faculty of Biology, Universitas Gadjah Mada (Yogyakarta, Indonesia) and were kept in $-20^{\circ} \mathrm{C}$ for further analysis.

DNAgenomic from muscle tissue of each sample was extracted using DNeasy Blood and Tissue Kit (Qiagen, USA) according to the supplier's protocol. COI mitochondrial gene of each sample was then amplified by polymerase chain reaction (PCR) using the universal primers FishF2 (5'TCGACTAATCATAAAGATATCGGCAC-3') and FishR2 (5'-ACT'TCAGGGTGACCGAAGAATCA GAA-3') designed by Ward et al. (2005). Each $25 \mu \mathrm{l}$ reaction contained $3 \mu \mathrm{l}$ (10-100 ng) DNA template, $12.5 \mu \mathrm{l}$ of MyTaq HS Red Mix PCR kit (Bioline), 2 $\mu \mathrm{l}$ of $2 \mathrm{mM} \mathrm{MgCl} 2,1.5 \mu \mathrm{l}$ of $0.6 \mu \mathrm{M}$ of each primer and $5.5 \mu \mathrm{l}$ double distilled water $\left(\mathrm{ddH}_{2} \mathrm{O}\right)$. A negative control has to be included for evaluating the reliability of the DNA amplification by omitting template DNA from the reaction mixture. PCR amplification conditions were $2 \mathrm{~min}$ predenaturation at $95^{\circ} \mathrm{C}$, followed by 35 cycles of denaturation at $95^{\circ} \mathrm{C}$ for $15 \mathrm{sec}$, annealing at $50^{\circ} \mathrm{C}$ for $30 \mathrm{sec}$, and extension at $72^{\circ} \mathrm{C}$ for $30 \mathrm{sec}$. A final extension of $5 \mathrm{~min}$ at $72^{\circ} \mathrm{C}$ was performed. We examined the PCR products on $1 \%$ agarose gels, 


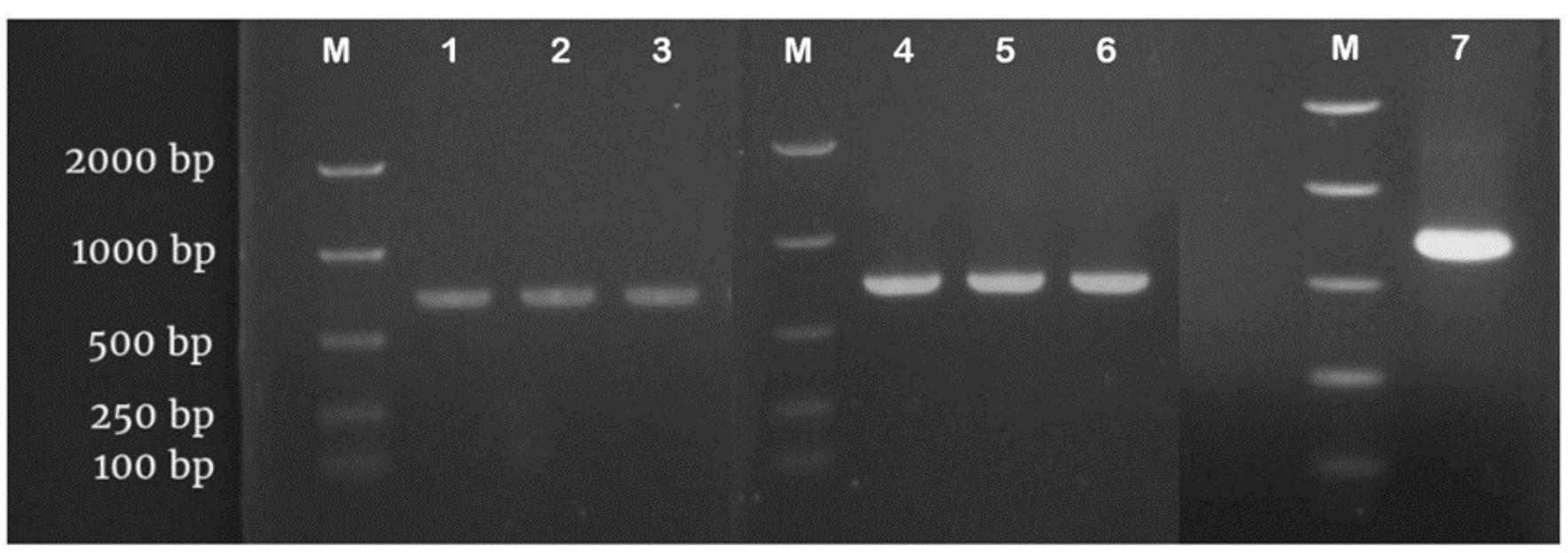

Figure 2. DNA profiles resulted from PCR amplification of COI mitochondrial genes of seven fish samples collected from Lake Lebo Taliwang, West Nusa Tenggara. $(M=$ marker $)$

purified with ExoSAP-IT'TMPCR purification kit (Applied Biosystems) and sequenced with the automated sequenced using the dye-termination method (Big Dye Terminator Ver. 3.1., Applied Biosystems), 20-50 ng purified PCR product, and 0.8 $\mu \mathrm{M}$ of either primer per reaction. The amplicons were sequenced in both forward and reverse directions. Fragments were then analyzed on an ABI 3500 Genetic Analyzer (Applied Biosystems) automated sequencer. DNA genomic from muscle tissue of each sample was extracted using DNeasy Blood and Tissue Kit (Qiagen, USA) according to the supplier's protocol. COI mitochondrial gene of each sample was then amplified by polymerase chain reaction (PCR) using the universal primers FishF2 (5'-TCGACTAATCATAAAGATATCGGCAC-3') and FishR2 (5'-ACTTCAGGGTGACCGAAGAAT CAGAA-3') designed by Ward et al. (2005). Each 25 $\mu \mathrm{l}$ reaction contained $3 \mu \mathrm{l}$ (10-100 ng) DNA template, $12.5 \mu \mathrm{l}$ of MyTaq HS Red Mix PCR kit (Bioline), $2 \mu \mathrm{l}$ of $2 \mathrm{mM} \mathrm{MgCl}, 1.5 \mu \mathrm{l}$ of $0.6 \mu \mathrm{M}$ of each primer and $5.5 \mu \mathrm{l}$ double distilled water $\left(\mathrm{ddH}_{2} \mathrm{O}\right)$. A negative control has to be included for evaluating the reliability of the DNA amplification by omitting template DNA from the reaction mixture. PCR amplification conditions were $2 \mathrm{~min}$ pre-denaturation at $95^{\circ} \mathrm{C}$, followed by 35 cycles of denaturation at $95^{\circ} \mathrm{C}$ for $15 \mathrm{sec}$, annealing at $50^{\circ} \mathrm{C}$ for $30 \mathrm{sec}$, and extension at $72^{\circ} \mathrm{C}$ for $30 \mathrm{sec}$. A final extension of $5 \mathrm{~min}$ at $72^{\circ} \mathrm{C}$ was performed. We examined the PCR products on 1\% agarose gels, purified with ExoSAP-ITTMPCR purification kit (Applied Biosystems) and sequenced with the automated sequenced using the dye-termination method (Big Dye Terminator Ver. 3.1., Applied Biosystems), 20-50 ng purified PCR product, and 0.8 $\mu \mathrm{M}$ of either primer per reaction. The amplicons were sequenced in both forward and reverse directions. Fragments were then analyzed on an ABI
3500 Genetic Analyzer (Applied Biosystems) automated sequencer.

\section{Data Analyses}

Forward and reverse sequences were edited and used to build consensus sequences with SeqMan and EditSeq (Lasergene, DNASTAR). The mitochondrial COI sequence of each specimen was converted into FASTA format and analysed using nucleotide BLAST (blast.ncbi.nlm.gov) and BOLD databases for species identity confirmation (www.boldsystems.org) (Ratnasingham and Hebert, 2007). The sequences were then aligned using opal multiple sequence alignment in MESQUITE v.3.51 (Madison \& Madison, 2018) and ClustalW in MEGA7 (Kumar et al., 2016). Next, sequences were compared by the Neighbour-Joining (NJ) method by applying the correction of the model Kimura 2parameter (K2P). The analysis of confidence estimates of the relations in the NJ trees was performed with a bootstrap analysis of 1000 replications with the program MEGA7 (Tamura et al., 2016). The NJ tree-based method was followed for the identification of unidentified specimens. This method assumed that query sequences belonged to a specific species if they were incorporated within a cluster (Pettengil and Maile, 2010). The barcode sequences of five fishes were taken from GenBank and BOLD for identifying species and as a comparative purpose, and the COI sequence of Penaeus monodon was extracted from GenBank for an outgroup.

\section{RESULT AND DISCUSSION}

The research result indicated that the seven samples of freshwater fishes can be well amplified (Figure 2). All of the COI sequences from seven fish samples revealed no insertion, deletions and stop codons. The PCR products of the seven samples have 
Table 1. Species identification based on GenBank database using BLAST analysis and BOLD identification

\begin{tabular}{lllcc}
\hline No & Sample Code & Identified species from GenBank/BOLD & Querry Cover (\%) & Similarity (\%) \\
\hline 1 & Sample-1 & Barbodes binotatus (MG699681) & 95 & 100 \\
2 & Sample-2 & Barbodes binotatus (MG699681) & 95 & 100 \\
3 & Sample-3 & Barbodes binotatus (MG699667) & 96 & 99.84 \\
4 & Sample-4 & Anabas testudineus (KU692243) & 100 & 99.81 \\
5 & Sample-5 & Anabas testudineus (KU692243) & 100 & 99.81 \\
6 & Sample-6 & Anabas testudineus (KU692243) & 100 & 99.81 \\
7 & Sample-7 & Tricogaster trichopterus & 97 & 99.57 \\
& & (synonym: Trichopodus trichopterus)* (KC789556) & & 100 \\
\hline
\end{tabular}

*Source: Fricke et al. (2019)

Parentheses in each species related to the accession number in the GenBank

fragment lengths as follow: sample 1 was $666 \mathrm{bp}$ (222 amino acid), sample 2 was 651 (217 amino acid), sample 3 was 636 bp (212 amino acid), sample 4 was 666 bp (222 amino acid), sample 5 was 703 (235 amino acid), sample 6 was 575 (179 amino acid), and sample 7 was 708 bp (236 amino acid). All of the COI sequences were submitted and published in the GenBank with the following accession numbers: samples 1-3 (MN640073-MN640075), samples 4-6 (MN640070-MN640072), and sample 7 (MN623381).

The nucleotide BLAST analysis result and identification through BOLD showed that the seven data of COI mitochondrial gene sequence of the fishes from the Lake Lebo Taliwang can could be grouped into three species (Table 1). The sequences of COI mitochondrial gene of sample 1,2 and 3 have similarity $99.8-100 \%$ if compared to Barbodes binotatus recorded in the GenBank database by applying BLAST analysis and BOLD identification. Therefore, the fish sample number 1, 2 and 3 were verified as Barbodes binotatus. Further, the sequence of COI mitochondrial gene of sample 4, 5, and 6 have similarity $99.84-100 \%$ if compared to Anabas testudineus as in the GenBank database by using BLAST analysis and through BOLD identification. It means the three fish samples (sample number 4, 5, and 6) were confirmed as Anabas testudineus. Next, the sequence of the COI mitochondrial gene of sample 7 has similarity $99.57-100 \%$ compared to Trichopodus trichopterus in the GenBank database through BLAST analysis and BOLD identification. Based on this analysis, the sample number 7 was verified as Trichopodus trichopterus. According to Yang et al. (2014), if the specimen has the similarity score between $98-100 \%$ with the species which has been recorded at the GenBank or BOLD, the specimen can be named as the identified species recorded at the GenBank or BOLD with that high score similarity.

The grouping of the three species was supported by the Neighbour Joining (NJ) tree (Figure 3). From Figure 3, it can be seen that sample 1,2 and 3 was clustered with Barbodes binotatus (accession number MG699667 and MG699681). Next, sample 4, 5 and 6 were clustered with Anabas testudineus (accession number KU692243) whereas sample 7 was clustered with Tricogaster trichopterus (accession number KC789556) and Trichopodus trichopterus (KU569063). According to Fricke et al. (2019), Tricogaster trichopterus is synonym with Trichopodus trichopterus.

The result of genetic identification by using COI mitochondrial gene as DNA barcoding had been able to detect seven samples collected from Lake Lebo Taliwang, West Nusa Tenggara and were classified into three species. It indicates that the sequence of the COI mitochondrial gene as a DNA barcoding marker can be used to identify the fish samples more accurately and quickly. In addition, the COI sequences from the three fish species can be implemented as the COI library sequences which are useful to identify the life cycle of the three species (egg, larvae, juvenile and adult).

\section{CONCLUSION}

The sequence of COI mitochondrial gene as a DNA barcoding marker was able to identify the seven samples of fishes from Lake Lebo Taliwang, West Nusa Tenggara, which were classified into three species, three samples were Barbodes binotatus, the other three samples were Anabas testudineus, and one sample was Trichopodus trichopterus. The COI sequences from the three fish species can be implemented as the COI library sequences. 


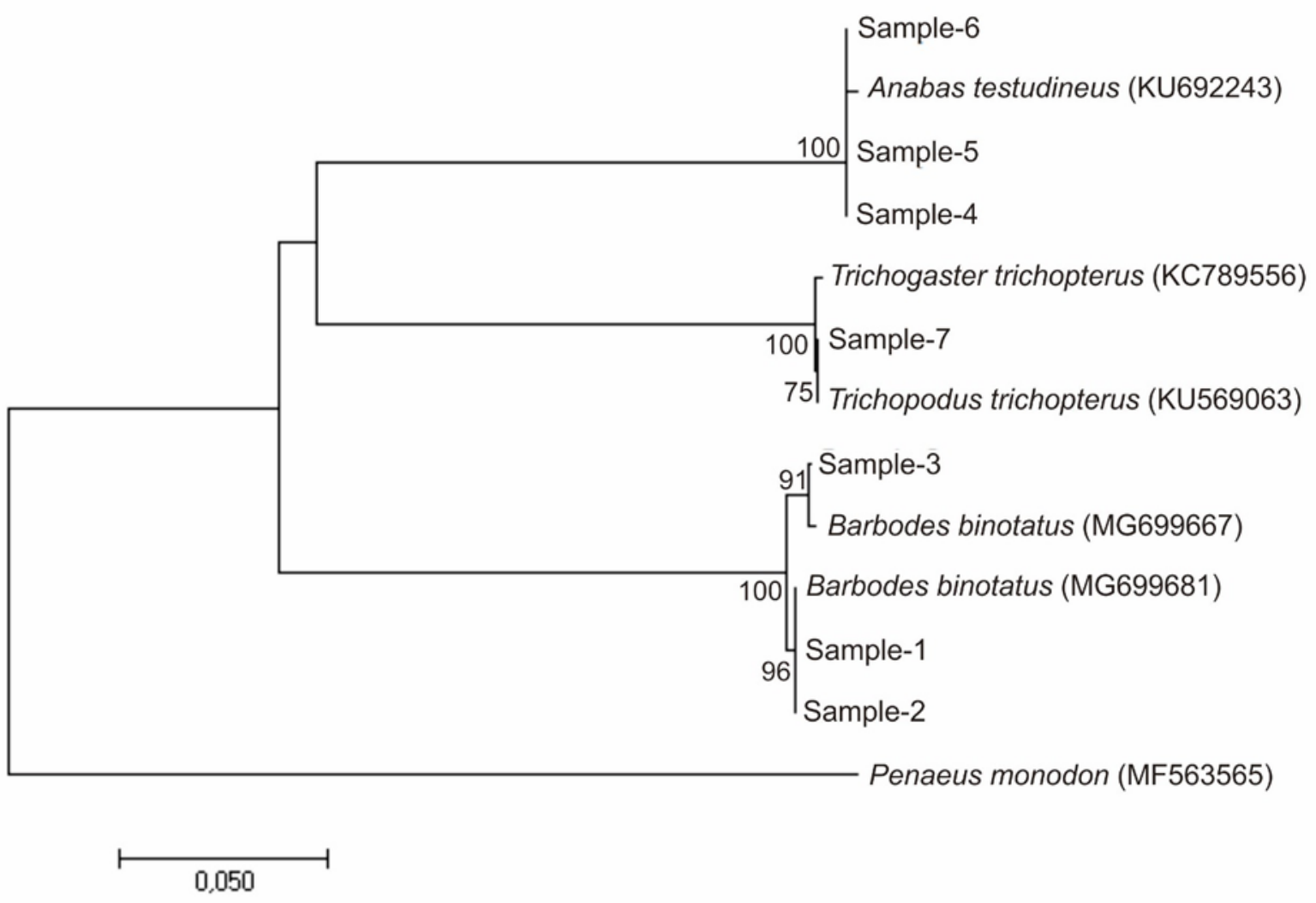

Figure 3. Neighbour-joining tree based on COI sequence data using the Kimura two-parameter (K2P) substitution model. The number at each node represents bootstrap and scale corresponds to substitution/site.

\section{ACKNOWLEDGEMENT}

The author sincerely appreciates the support from the Head of the Laboratory of Genetics and Breeding, Faculty of Biology UGM, and the Head of Integrated Research and Testing Laboratory (LPPT) UGM, who have provided facilities and tools for this research.

\section{REFERENCES}

Arif, I.A. \& Khan, H.A., 2009, Molecular markers for biodiversity analysis of wild animals: a brief review, Animal Biodiversity and Conservation, 32(1), 9-17.

Arisuryanti, T., Hasan, R.L. \& Koentjana, J.P., 2018, Genetic identification of two mudskipper species (Pisces: Gobiidae) from Bogowonto Lagoon (Yogyakarta, Indonesia) using COI mitochondrial gene as a DNA barcoding marker, AIP Conference Proceedings, 2002, 020068 (1)-020068(7).

Chauhan, T. \& Rajiv, K., 2010, Molecular markers and their applications in fisheries and aquaculture, Advances in Bioscience and Biotechnology, 01(04), 281-291.
Dahruddin, H., Hutama, A., Busson, F., Sauri, S., Hanner, R., Keith, P., Hadiaty, R., \& Hubert, N., 2017, Revisiting the ichthyodiversity of Java and Bali through DNA barcodes: taxonomic coverage, identification accuracy, cryptic diversity and identification of exotic species, Molecular Ecology Resources, 17(2), 288299.

Dudu, A., Barbălată, T., Popa, G., Georgescu, S.E., Costache, M., 2016, Advantages and limitations of DNA Barcoding in identifying commercially-exploited fish species, Animal Science and Biotechnologies, 49 (1), 45-49.

Fricke, R., Eschmeyer, W. N. \& Van der Laan, R., 2019, Eschmeyer's catalog of fishes: genera, species, references, viewed 1 June 2019, http: / / researcharchive.calacademy.org/ research/ichthyology/catalog/fishcatmain.asp.

Haryani, G., 2013, Kondisi danau di Indonesia dan strategi pengselolaannya. Prosiding Pertemuan Ilmiah Tabunan Masyarakat Limnologi Indonesia I, 1-19.

Hebert, P.D., Ratnasingham, S. \& deWaard, J.R., 2003, Barcoding animal life: cytochrome c oxidase subunit 1 divergence among closely related species, Proceedings of the Royal Society B: Biological Sciences, 270 Suppl 1, S96-99. 
Hutama, A., Dahruddin, H., Busson, F., Sauri, S., Keith, P., Hadiaty, R.K., Hanner, R., Suryobroto, B. \& Hubert, N., 2017, Identifying spatial concordant evolutionary significant units across multiple species through DNA barcodes: Application to the conservation genetics of the freshwater fishes of Java and Bali, Global Ecology and Conservation, 12, 170-187.

Kumar, S., Stecher, G., \& Tamura, K., 2016, MEGA7: molecular evolutionary genetic analysis version 7.0 for bigger datasets, Molecular Biology and Evolution, 33(7), 18701874.

Librado, P., \& Rozas, J., 2009, DnaSP v5: a software for comprehensive analysis of DNA polymorphism data. Bioinformatics, 25(11), 1451 $-1452$.

Maddison, W.P., \& Maddison, D.R., 2018, Mesquite: A modular system for evolutionary analysis. Version 3.51 http://www.mesquiteproject.org.

Peninal, S., Subramanian, J., Elavarasi, A. \& Kalaiselvam, M., 2017, Genetic identification of marine eels through DNA barcoding from Parangipettai coastal waters. Genomics Data, 11, 81-84.

Pettengill, J.B. \& Maile, C.N., 2010, An evaluation of candidate plant DNA barcodes and assignment methods in diagnosing 29 species in the genus Agalinis (Orobanchaceae). American Journal of Botany, 97,1391-1406.
Ratnasingham, S. \& Hebert, P.D.N., 2007, BOLD: The barcode of life data system (www.barcodinglife.org). Molecular Ecology Notes, 7, 355-364.

RIPED, 2008, Lebo Taliwang, kekayaan flora dan fauna Sumbawa Barat, viewed 27 February 2019, http://konservasi4lebotaliwang. blogspot.com

Syaifudin, M., Jubaedah, D., Muslim, M. \& Daryani, A., 2017, DNA authentication of Asian Red Catfish Hemibragus nemurus from Musi and Penukal River, South Sumatra Indonesia. Genetics of Aquatic Organisms, 1, 43-48.

Yang, L., Tan, Z.,Wang, D., Xue, L., Guan, M-X., Huang, T. \& Li, R., 2014, Species identification through Mitochondrial rRNA genetic analysis. Scientific Reports, 4:4089.

Yudhistira, A \& Arisuryanti, T., 2019, Preliminary findings of cryptic diversity of the giant tiger shrimp (Penaeus monodon Fabricius, 1798) in Indonesia inferred from COI mitochondrial DNA. Genetika, 51, 261-270.

Ward, R.D., Zemlak, T.S., Innes, B.H., Last, P.R., \& Hebert, P.D.N., 2005, DNA barcoding Australia's fish species. Philosophical Transactions of the Royal Society B, 360(1462), 1847-1857. 